\title{
Breekpuntervarings is geloofservarings
}

Book Title:

Wanneer die lewe nuut begin: Breekpuntervarings in die lewens van Bybelkarakters

Book Cover:

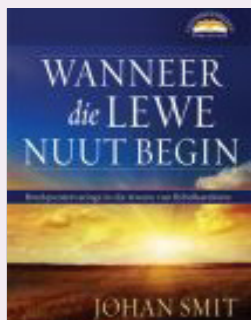

Author:

J. Smit

ISSN:

978-1-77000-887-8

Publisher:

Christelike

Uitgewersmaatskappy,

Vereeniging, 2010, R119.95

*Book price at time of review

$\square$

Review title:

Breekpuntervarings is

geloofservarings

Reviewer:

Piet Venter ${ }^{1}$

\section{Affiliation:}

${ }^{1}$ Gereformeerde Kerk

Potchefstroom-Oos,

Suid-Afrika

Email:

dspietventer@oosdoppers.

co.za

Postal address:

Rocher Street 75,

Potchefstroom 2531

How to cite this book review:

Venter, P., 2013,

'Breekpuntervarings is

geloofservarings', In die

Skriflig/In Luce Verbi 47(1)

Art. \#122, 1 page. http://

dx.doi.org/10.4102/ids.

v47i1.122

Read online:

Scan this QR
code with your
smart phone or
mobile device
to read online.

Johan Smit neem die leser op 'n besondere geestelike ervaring en leerproses deur te kyk na verskeie 'breekpuntervarings' in die lewens van bybelse figure. Met 'n breekpuntervaring bedoel die skrywer dat daar in die lewe van bybelfigure soos Abraham, Moses, Paulus en andere 'n keerpunt, draaipunt of breekpunt kom wat hulle lewens op 'n nuwe koers plaas. 'n Voorbeeld hiervan is God se openbaring aan Moses by die brandende bos in die woestyn in Eksodus 3 toe sy lewe dramaties verander het.

Deur die breekpuntervarings saam te deurleef, leer die lesers om hulle lewens in oënskou te neem en te vra na die breekpuntervarings in hulle eie lewe en wat God daardeur wou bewerk. Die lesers leer om meer opmerksaam te wees vir dit wat God in hulle lewens openbaar en hoe Hy elkeen se lewe stuur en rig.

Die skrywer lig in 12 hoofstukke verskeie breekpuntervarings van agt Ou-Testamentiese en 12 Nuwe-Testamentiese gelowiges uit waardeur die lesers kan leer om hulle eie breekpuntervarings te evalueer. Die skryfstyl is gemaklik en deurspek met humor en skerpsinnige waarnemings. Enkele voorbeelde hiervan is die opmerking oor een van die grootste breekpuntervarings in die lewe van Josef 'Van tronkvoël tot eerste minister in een dag se tyd - dit wil gedoen wees'! Wanneer Smit skryf oor die breekpuntervaring van die profeet Elia op die berg Karmel teen die 450 priesters van Baäl, noem hy hulle "n heidense sinode'. Wanneer Elia na hierdie gebeurtenis die woestyn invlug en onder ' $n$ besembos gaan lê met die wens om te sterf, stel die skrywer dit dat 'Elia vra om te sterf, en in plaas van ' $n$ begrafnisondernemer kry hy toe 'n engel! En in plaas van 'n doodsertifikaat kry hy kos om te eet'! Hierdie skryfstyl boei die lesers tot die einde toe.

Die verskillende beskrywings van die breekpuntervarings is deurlopend veranker in bybelsgefundeerde teologiese waarhede en riglyne vir die verstaan van die lesers se eie breekpuntervarings. So word daar genoem dat God persoonlik teenwoordig is in die lewe van sy kinders en dat Hy Homself aan jou openbaar in breekpuntervarings; ook dat breekpuntervarings geloofsvolharding toets. Dit word ook gestel dat sulke ervarings 'n karaktertoets is en dat God selfs die gelowige se verkeerde besluite en sondige optrede gebruik om sy doelwit te bereik. Na aanleiding van Romeine 8:28 word voorts duidelik aangedui dat God alles in die lewe van die gelowige ten goede beskik en dat 'n mens daarin kan berus. 'n Ander belangrike doel van God met breekpuntervarings is ook om jou lewe van sonde te suiwer. Die skrywer se hantering van die Skrif berus op goeie insig en ervaring en hy lewer weldeurdagte en grondige kommentaar wat tot die leser se eie omstandighede spreek.

Sommige breekpuntervarings het ook implikasies vir die kerk van die Here en die skrywer toon duidelik aan hoe God individuele gelowiges, byvoorbeeld Moses, gebruik om die totale voortgang en koers van die kerk van die Ou Testament te beïnvloed en te bepaal. So kry die gelowige ook visie met betrekking tot die wyse waarop God jou in sy koninkryk wil gebruik. Dieselfde geld vir die breekpuntervarings van Paulus.

$\mathrm{Na}$ die beskrywing van elke breekpuntervaring is daar telkens vir die leser ' $n$ aantal selfondersoekende vrae wat help om dit wat hy byvoorbeeld van Petrus gelees het, ook in sy eie lewe van toepassing te maak. Die boek help die gelowige om 'n positiewe gesindheid oor breekpuntervarings in sy lewe te ontwikkel en hoe 'n mens meer intiem met God op die pad van die geloof kan omgaan. Dit leer die gelowige ook hoedat God jou lewe in sy diens gebruik en dat selfs negatiewe ervarings uiteindelik positiewe uitkomste oplewer.

Aan die einde van die boek is daar enkele wenke en riglyne om 'n Bybelstudiegroep te lei. Hierdie boek spreek werklik tot ' $n$ wye verskeidenheid gelowiges, maar sal veral vir gelowiges wat deur krisistye in hulle lewens gaan van groot waarde wees. 